\title{
Plasmodium vivax and Plasmodium falciparum ex vivo susceptibility to anti-malarials and gene characterization in Rondônia, West Amazon, Brazil
}

\author{
Anna Caroline C Aguiar ${ }^{1,2}$, Dhelio B Pereira ${ }^{3}$, Nayra S Amaral ${ }^{2}$, Luiz De Marco ${ }^{2}$ and Antoniana U Krettli, 1,2*
}

\begin{abstract}
Background: Chloroquine (CQ), a cost effective antimalarial drug with a relatively good safety profile and therapeutic index, is no longer used by itself to treat patients with Plasmodium falciparum due to CQ-resistant strains. P. vivax, representing over $90 \%$ of malaria cases in Brazil, despite reported resistance, is treated with CQ as well as with primaquine to block malaria transmission and avoid late $P$. vivax malaria relapses. Resistance to CQ and other antimalarial drugs influences malaria control, thus monitoring resistance phenotype by parasite genotyping is helpful in endemic areas.
\end{abstract}

Methods: A total of 47 P. vivax and nine $P$. falciparum fresh isolates were genetically characterized and tested for $C Q$, mefloquine (MQ) and artesunate (ART) susceptibility in vitro. The genes $m d r 1$ and pfcrt, likely related to CQ resistance, were analyzed in all isolates. Drug susceptibility was determined using short-term parasite cultures of ring stages for 48 to 72 hour and thick blood smears counts. Each parasite isolate was tested with the antimalarials to measure the geometric mean of 50\% inhibitory concentration.

Results: The low numbers of $P$. falciparum isolates reflect the species prevalence in Brazil; most displayed low sensitivity to CQ (IC50 $70 \mathrm{nM})$. However, CQ resistance was rare among $P$. vivax isolates (IC $C_{50}$ of $\left.32 \mathrm{nM}\right)$. The majority of $P$. vivax and $P$. falciparum isolates were sensitive to ART and MQ. One hundred percent of $P$. falciparum isolates carried non-synonymous mutations in the pfmdr1 gene in codons 184, 1042 and 1246, 84\% in codons 1034 and none in codon 86, a well-known resistance mutation. For the pfcrt gene, mutations were observed in codons 72 and 76 in all $P$. falciparum isolates. One $P$. falciparum isolate from Angola, Africa, showing sensitivity to the antimalarials, presented no mutations. In $P$. vivax, mutations of pvmdr1 and the multidrug resistance gene 1 marker at codon F976 were absent.

Conclusion: All P. falciparum Brazilian isolates showed CQ resistance and presented non-synonymous mutations in pfmdr1 and pfcrt. CQ resistant genotypes were not present among $P$. vivax isolates and the $I_{50}$ values were low in all samples of the Brazilian West Amazon.

Keywords: Anti-malarials, Resistance, Plasmodium vivax, Plasmodium falciparum, Chloroquine resistance

\footnotetext{
* Correspondence: akrettli@cpqrr.fiocruz.br

'Laboratório de Malária, Centro de Pesquisas René Rachou, FIOCRUZ, Av.

Augusto de Lima 1715, 30190-002 Belo Horizonte, MG, Brazil

${ }^{2}$ Faculdade de Medicina, Universidade Federal de Minas Gerais, Belo

Horizonte, MG, Brazil

Full list of author information is available at the end of the article
} 


\section{Background}

Malaria, one of the most prevalent parasitic diseases in the world, still causes high morbidity and death, mainly in Plasmodium falciparum-infected, non-treated patients [1]. Plasmodium vivax causes intense morbidity and contributes to significant political, social and economic instability in developing countries of Latin America and Asia $[2,3]$. CQ is the drug of choice to treat vivax malaria in endemic areas of Brazil and primaquine (PQ) is used to avoid late malaria relapses [3]. The recommended dose for adults is $1500 \mathrm{mg}$ of CQ (daily for three days) and $210 \mathrm{mg}$ of PQ (daily for seven days) [4]. Plasmodium vivax resistance is now widespread and has rendered CQ ineffective in parts of Indonesia and Papua New Guinea [5-7]. Low levels of resistance have also been reported in Myanmar, South Korea, Vietnam, India, Turkey, Ethiopia, and in regions of Southern Africa and South America $[3,8,9]$. The occurrence of severe vivax malaria and patient's deaths has been reported in Brazil [10-12] raising the possibility of an association between malaria severity and drug resistance [13]. In areas of CQ resistance, treatment of uncomplicated P. falciparum malaria is carried out with artemisinin-based combination therapy (ACT) [3]. Drugs that complement ACT include lumefantrine, amodiaquine, $\mathrm{AQ}, \mathrm{MQ}$, sulphadoxine-pyrimethamine and antibiotics. In Brazil, the first option for falciparum malaria treatment is the combination of artemether (480 mg daily for four days) and lumefantrine (2880 mg daily for four days). PQ (45 mg) is administrated on day one to avoid malaria transmission. These doses are recommended for adults with $50 \mathrm{Kg}$ weight or more [4]. A reduced susceptibility to artemisinin derivatives has been described in $P$. falciparum-treated patients $[14,15]$.

Increasing evidence of a lower $P$. vivax susceptibility to CQ in malaria-endemic areas [16] includes the state of Amazonas [17] and is believed to be associated with malaria's clinical severity [18].

Molecular markers associated with CQ resistance are nonsynonymous mutations in the drug/metabolite transporter gene $p f c r t$ (C72S, K76T) and in the multidrug resistance protein 1 gene pfindr1 (N86Y; Y184F; S1034C; N1042D; D1246Y), described in P. falciparum [19-21]. One mutation of the multidrug resistance gene 1 (Y976F) of $P$. vivax is also associated with parasite susceptibility to CQ [8]. A nonsynonymous mutation of the pvdhps gene at codon 382 (S382C) was recently associated with in vitro susceptibility to CQ [18]. The present study aimed to examine the phenotypic and genotypic chemoresistance profile of $P$. falciparum and $P$. vivax to commonly used anti-malarial drugs in a Brazilian malaria-endemic area in the Amazon Region.

\section{Methods}

\section{Subjects}

All isolates were collected between August 2012 and March 2013 from patients recruited at the Centre of
Malaria Control (CEPEM) in the city of Porto Velho, state of Rondônia, in the Brazilian Western Amazon, where $P$. vivax is highly prevalent. Only patients monoinfected with either $P$. falciparum or $P$. vivax and with high parasitaemia (between 2,000 and 80,000 parasites/ $\mu \mathrm{l})$ were recruited. Patients who used any anti-malarial in the previous month and/or presented severe symptoms of malaria were excluded from this work. The study cohort encompassed 56 patients living in this highly endemic area which is close to Bolivia (Figure 1). Forty seven patients were diagnosed with $P$. vivax and eight with $P$. falciparum. In addition, one isolate of an individual infected with $P$. falciparum with imported malaria (from Africa) was also studied. One patient had mixed malaria (P. vivax and P. falciparum) and was not included. From each volunteer, a peripheral venous blood sample $(5 \mathrm{ml})$ was collected by venipuncture in heparin-containing tubes and immediately used for the ex vivo drug susceptibility assay using pre-prepared plates with the diluted anti-malarials, as described below. DNA was also extracted from peripheral venous blood in EDTA containing tubes for parasite genomic analysis.

\section{Ethical approval}

This study was approved by the Ethics Committee, Centro de Pesquisas René Rachou-FIOCRUZ (CAAE -03209212. 7.0000.5091). All participants signed a written informed consent before blood collection.

\section{Pre-dosed plates with test and control drugs}

$\mathrm{CQ}, \mathrm{MQ}$ and ART were prepared as $10 \mu \mathrm{g} / \mathrm{mL}$ stock solution in dimethyl sulphoxide (DMSO) in 96-well plates (20 $\mu \mathrm{L}$ per well), then diluted two-fold in RPMI, with variable maximum drug concentration according to each previously determined activity (shown in parentheses), i.e. CQ (854 nM), MQ (724 nM), ART (738 nM), lyophilized and stored at $4^{\circ} \mathrm{C}$ until further use. Each lot of plates was assayed for quality control just before use, based on the profile response to $\mathrm{CQ}$ to the $P$. falciparum laboratory strains W2 and 3D7, for CQ-resistance and -sensitivity, respectively. All plates were prepared in our laboratory, in Belo-Horizonte, transported to the field in dry ice and kept at minus $70^{\circ} \mathrm{C}$ until use.

\section{Ex vivo drug susceptibility assay}

The drug susceptibility of the malaria parasites, from each patient, was measured in vitro. For P. falciparum the method used was described by Rieckmann and Antuñano [22] and for P. vivax by Renapurkar et al. [23] with modifications [24]. White blood cells were removed by filtration in a CF 11 cellulose column as described [25]. Immediately before the ex vivo drug susceptibility assays, packed red blood cells with the parasites (iRBC) were diluted for a $2 \%$ hematocrit, using either complete medium 


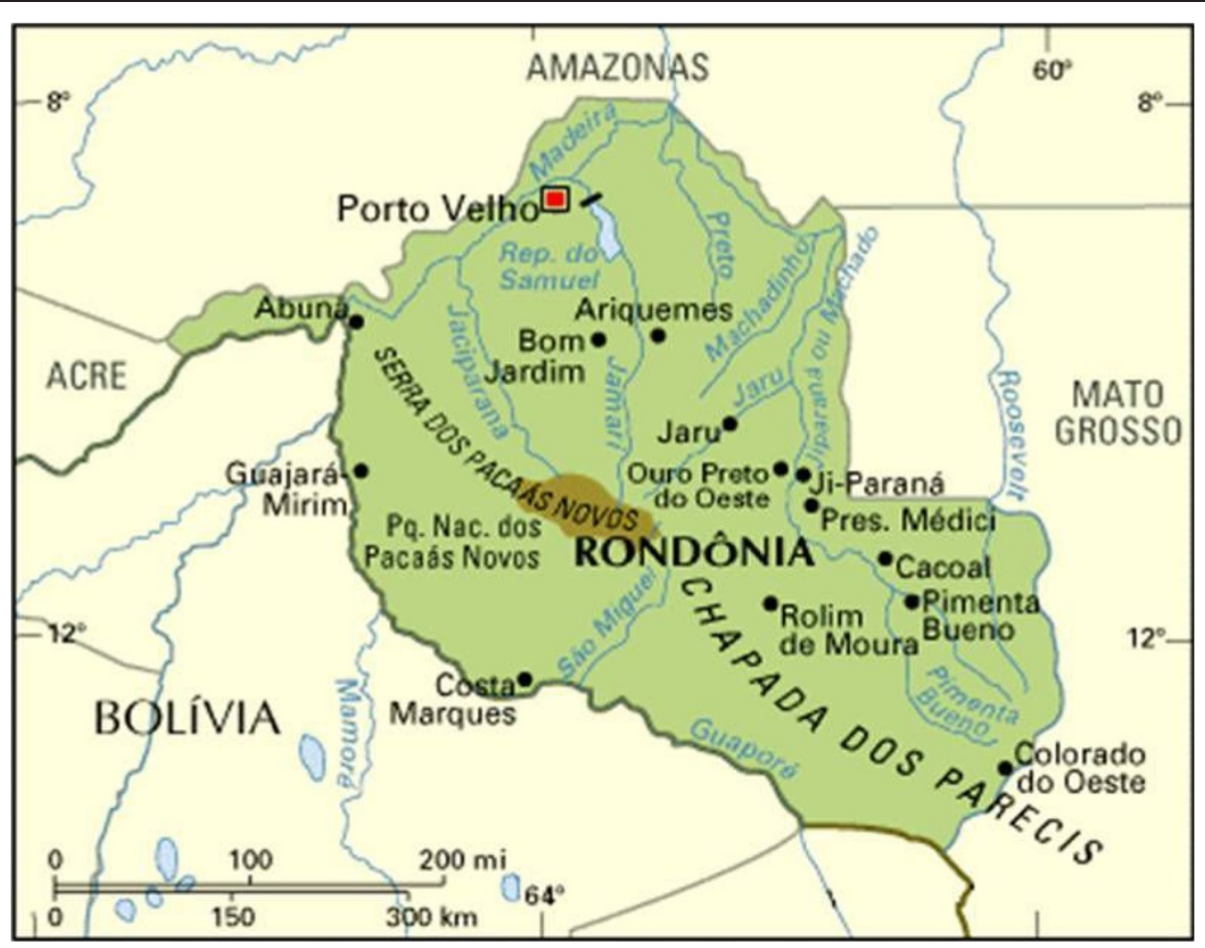

Figure 1 Rondônia state, West Amazon.

RPMI 1640 medium plus 10\% AB human serum, with $P$. falciparum cultures; or the McCoy's 5A medium plus $20 \%$ $\mathrm{AB}$ human serum, with $P$. vivax samples. The iRBC (200 $\mu \mathrm{l}$ per well) were distributed in the pre-dosed drug plate. For the maturation of parasites, rings to schizonts, the plates were maintained in candle jars at $37^{\circ} \mathrm{C}$ as described [26], at different incubation times (48-72 hours). The control wells were iRBCs and cultured with drug free complete medium. The incubation parasite-drug was stopped when $40 \%$ of the ring stages reached the schizont stage (at least four distinct nuclei per parasite) in the drug-free control wells ( $n=6$ per plate). Thick blood films were then made from each well, dried, stained with $5 \%$ Giemsa solution for $30 \mathrm{~min}$, and examined microscopically. The number of schizonts per 100 asexual stage parasites was determined for each drug concentration and then normalized by comparing with the schizont number in the drug-free control wells (considered as 100\%). The half-maximal drug inhibitory response $\left(\mathrm{IC}_{50}\right)$ was estimated by curve fitting using software (OriginLab Corporation, Northampton, MA, USA) and comparing with parasite growth in the drug-free controls.

Table 1 Set of primer sequences used to characterize gene polymorphisms by Plasmodium falciparum and $P$. vivax

\begin{tabular}{|c|c|c|c|c|}
\hline Gene & Codons & Primer & $\mathrm{AT}^{*}\left({ }^{\circ} \mathrm{C}\right)$ & PCR products (bp) \\
\hline \multirow[t]{6}{*}{ pfmdr1 } & 86,184 & 5'-GAGTTGAACAAAAAGAGTACCGCTGA-3' & 55 & 512 \\
\hline & & 5'-TTाTCCGTTAATTTATGTTTGTGGTGTCA-3' & & \\
\hline & 1043,1042 & 5'-TGTCAAGCGGAGTITTTGCATTTAGT-3' & & 299 \\
\hline & & 5'-TGGTAGTTATGCTGGAAAATTAATGTCCT-3' & & \\
\hline & 1246 & 5'-GGAGAAACAGGTAGTGGAAAATCAACTT-3' & & 302 \\
\hline & & 5'-TTTGGAAGAGAAGATGCAACATTGGAA-3 & & \\
\hline \multirow[t]{2}{*}{ pvmdr1 } & 976 & 5'-ACTCACTTTATAGTGCTCTTCCTTGTG-3' & 55 & 476 \\
\hline & & 5'- GGACATCAACTTCCCGGCGT- 3' & & \\
\hline \multirow[t]{2}{*}{ pfcrt } & 72,76 & 5'- acagATGGCTCACGTTTAGG -3' & 55 & 162 \\
\hline & & $5^{\prime}-$ TाTाGTAACATCCGAAACTCACA -3' & & \\
\hline
\end{tabular}


Table 2 Characteristics of the study population with malaria in the Amazon-Brazil

\begin{tabular}{lcc}
\hline & P. falciparum & P. vivax \\
\hline Number of patients & $\mathbf{9}$ & $\mathbf{4 7}$ \\
Male (age) & $\mathrm{N}=6(41 \pm 4)$ & $\mathrm{N}=37(37 \pm 10)$ \\
Female (age) & $\mathrm{N}=3(22 \pm 3)$ & $\mathrm{N}=10(47 \pm 13)$ \\
Fever at the time of blood collection & 9 & 42 \\
\hline
\end{tabular}

\section{Real time PCR for Plasmodium detection}

Genomic DNA of the parasites was extracted using QIAamp DNA kit (QIAGEN, Chatsworth, CA, USA) and then subjected to real time PCR (Applied Biosystems ${ }^{\oplus}$ ). The 18S rRNA gene was chosen as target gene since it contains both highly conserved and variable regions (at least five copies of the gene are dispersed on separate chromosomes of the Plasmodium genome). Each $20 \mu \mathrm{l} \mathrm{re-}$ action mix contained $2 \mu \mathrm{l}$ of sample DNA, $10 \mu \mathrm{l}$ FastSTART DNA SYBR Green reagent (Roche), $6.5 \mathrm{mM}$ $\mathrm{MgCl} 2$ (final concentration), and $0.5 \mathrm{mM}$ concentrations of each primer (5'-TAACGAACGAGATCTTAA-3' and 5'-GTTCCTCTAAGAAGCTTT-3'). The PCR conditions consisted of an initial denaturation at $95^{\circ} \mathrm{C}$ for $10 \mathrm{~min}$, followed by amplification for 40 cycles of $10 \mathrm{sec}$ at $95^{\circ} \mathrm{C}$, $5 \mathrm{sec}$ at $50^{\circ} \mathrm{C}$, and $20 \mathrm{sec}$ at $72^{\circ} \mathrm{C}$, with fluorescence acquisition at the end of each extension step. Amplification was immediately followed by a melt programme, consisting of $2 \mathrm{~min}$ at $95^{\circ} \mathrm{C}, 2 \mathrm{~min}$ at $68^{\circ} \mathrm{C}$, and a stepwise temperature increase of $0.2^{\circ} \mathrm{C} / \mathrm{sec}$ until $90^{\circ} \mathrm{C}$, with fluorescence acquisition at each temperature transition. Fluorescence was analysed using F1/F2 settings, which improved the detection of P. falciparum (a cutoff of 35 cycles was used to define Plasmodium-positive samples). A melting curve analysis was used to determine the species-specific mean melting temperature $(\mathrm{Tm})$ based on values determined from the respective positive controls [27].

\section{Analysis of the crt and mdr1 genes}

The pfcrt and mdr1 genes were amplified by PCR with specific primers for each region (Table 1). The PCR reactions were performed with $3 \mu \mathrm{l}$ of DNA at $30 \mathrm{ng} / \mu \mathrm{l}$, mixed with $6.5 \mu \mathrm{l}$ of AmpliTaq Gold ${ }^{\oplus}$ PCR Master Mix (Applied Biosystems, Warrington, UK), $0.5 \mu \mathrm{l}$ of each primer at
$10 \mathrm{pmol} / \mu \mathrm{l}$, on a final volume of $15 \mu \mathrm{l}$. The samples were placed in an Eppendorf Mastercycler (Hamburg, Germany) at $94^{\circ} \mathrm{C}$ for $3 \mathrm{~min}$ followed by 35 cycles of $94^{\circ} \mathrm{C}$ for $30 \mathrm{sec}, 55^{\circ} \mathrm{C}$ for $30 \mathrm{sec}$ and $72^{\circ} \mathrm{C}$ for $30 \mathrm{sec}$ and a final extension time at $72^{\circ} \mathrm{C}$ for $5 \mathrm{~min}$. PCR products were purified using Wizard PCR DNA and Gel Band Purification Kit (Promega, Madison, USA) following manufacturer's protocol and visualized on a silver-stained 6.5\% polyacrylamide gel. Purified DNA fragments were then sequenced using the dideoxy method. Sequence data were analysed using Sequencher 4.9 software (Gene Codes Co, Ann Arbor, MI, USA). Sequences were then compared with those on Plasmo DB gene bank.

\section{Results}

\section{Anti-malarial susceptibility}

Ex-vivo drug susceptibility was assessed in field isolates from all 56 patients with a single species infection, either P. vivax ( $\mathrm{n}=47)$ or $P$. falciparum $(\mathrm{n}=9)$; eight of the latter were Brazilian isolates freshly collected in the state of Rondônia, in the Brazilian Western Amazon (Figure 1) and one was from an individual returning from Angola, Africa, diagnosed and studied in Belo Horizonte, Brazil, outside the endemic malaria region.

Adequate parasite growth was achieved in 100\% (9/9) of the P. falciparum and in 68\% (32/47) of $P$. vivax isolates. The characteristics of these isolates are summarized in Table 2 . The majority of $P$. falciparum Brazilian isolates studied were considered resistant to $\mathrm{CQ}\left(\mathrm{IC}_{50} 70\right.$ $\mathrm{nM}$; range, 0.19 to $223 \mathrm{nM}$ ); two susceptible showed $\mathrm{IC}_{50}$ values of 0.19 and $37 \mathrm{nM}$; two isolates were considered resistant to MQ ( $\mathrm{IC}_{50}$ of 50 and $63 \mathrm{nM}$ ); but, all isolates were susceptible to $\mathrm{ART}$, since the highest $\mathrm{IC}_{50}$ was $5.8 \mathrm{nM}$.

Among the $P$. vivax isolates the results of drug susceptibility to $\mathrm{CQ}$ suggests no resistance; the median $\mathrm{IC}_{50}$ was $32 \mathrm{nM}$; ranging between 3 to $69 \mathrm{nM}$ (Table 3); four isolates (P010, P024, P026, P042) less susceptible to CQ showed $\mathrm{IC}_{50}$ values higher than $51 \mathrm{nM}$. In further analysis 32 were examined in the thick smears for the stages of the parasite blood forms; three patients had approximately $30 \%$ of parasites in trophozoite stage, which is considered a high rate. And, they present high $\mathrm{IC}_{50}$ values to $\mathrm{ART}$

Table 3 Overall ex-vivo sensitivity of Brazilian isolates for each drug, according to the species tested, and for laboratory P. falciparum (W2 clone) line, chloroquine resistant

\begin{tabular}{|c|c|c|c|c|c|c|c|}
\hline \multirow[t]{3}{*}{ Drug } & \multicolumn{5}{|c|}{ P. falciparum } & \multirow{2}{*}{\multicolumn{2}{|c|}{ P. vivax Clinical field isolates }} \\
\hline & \multirow[t]{2}{*}{ W2 } & \multirow{2}{*}{$\begin{array}{l}\mathrm{Fc} 27^{*} \\
\mathrm{IC}_{50}(\mathrm{nM})\end{array}$} & \multirow[t]{2}{*}{ African } & \multicolumn{2}{|c|}{ Clinical field isolates } & & \\
\hline & & & & $\mathrm{n}$ & Median $\mathrm{IC}_{50}(\mathrm{nM})^{* *}$ & $\mathrm{n}$ & Median $\mathrm{IC}_{50}(\mathrm{nM})$ \\
\hline Chloroquine & 178 & 39 & 19 & 9 & $70(0.19-223 ; 80)$ & & $32(3-69 ; 64)$ \\
\hline Artesunate & 18 & 16 & 1.5 & 9 & $1.3(0.26-5.8 ; 2.82)$ & 32 & $21(0.08-137 ; 17.4)$ \\
\hline Mefloquine & 19 & 11 & 46 & 9 & $21(1.19-63 ; 80)$ & & $57(5.0-113 ; 82)$ \\
\hline
\end{tabular}

*Date from Marfurt et al. [28,29]. ${ }^{* *}$ The numbers inside of the parenthesis means: lowest $I C_{50}$, higher $I C_{50}$ and interquartile range. 
Table 4 Anti-malarial activity in vitro in 15 different human $P$. vivax isolates for chloroquine (CQ), artesunate (ART) and mefloquine MQ)

\begin{tabular}{ccccc}
\hline P. vivax isolates & \% of trophozoites & \multicolumn{3}{c}{ Drugs//I $\mathbf{C}_{50} \mathbf{N m}$} \\
\cline { 3 - 5 } & & CQ & ART & MQ \\
\hline P006 & 22 & 29 & 15 & 11 \\
P010 & 20 & $61^{* *}$ & 11 & 45 \\
P015 & 9 & 13.5 & 11 & 6 \\
P022 & 15 & 8 & 11 & 60 \\
P024 & $32^{*}$ & $69^{* *}$ & 34 & 113 \\
P025 & $93^{*}$ & 3.0 & 28 & 11 \\
P026 & 29 & $51^{* *}$ & 137 & 42 \\
P028 & 11 & 6.6 & 2.8 & 11 \\
P029 & 16 & 34 & 2.5 & 5.5 \\
P031 & 10 & 15 & 8.0 & 8.2 \\
P033 & 8 & 23 & 23 & 24 \\
P034 & 17 & 29 & 9.6 & 47 \\
P038 & $42^{*}$ & 8.5 & 1.3 & 2 \\
P037 & $32^{*}$ & 6.5 & 9.4 & 39 \\
P039 & $88^{*}$ & 6.8 & 5.2 & 26 \\
P042 & $80^{*}$ & $62^{* *}$ & 23 & 15 \\
Mean ( \pm SD) & - & $23+9$ & $32+37$ & $32+28$ \\
\hline
\end{tabular}

*Isolates that presented more than $30 \%$ trophozoites. ${ }^{* *}$ Isolates that were considered less sensitive to $\mathrm{CQ}$.

and MQ (Table 4). However this number is not enough to show a strong association between stage-specificity and drug activities and future studies are needed. The only African isolate studied was susceptible to the antimalarials tested (Table 3).

\section{Characterization of the $C R T$ and MDR1 resistance}

The parasite profiles of molecular resistance for $P$. vivax isolates, using the frequencies of SNPs (Single Nucleotide Polymorphism) in pvmdrl codon 976, were examined in 47 samples (Table 1). The product was compared with the genomic sequence of Salvador I as the reference wild type found in the Plasmo DB gene bank, and no SNPs were found. For P. falciparum isolates, frequencies of SNPs in pfmdr 1 codons 86, 184, 1034, 1042 and 1246 are shown in Table 5. In addition, codons 72 and 76 of pfcrt gene were also evaluated (Table 5). Mutant alleles at positions 184, 1042 and 1246 on pfmdr1 gene were present in 100\% of the samples. In codon 1034, the frequency of mutation was $84 \%$ and no mutations were found in codon 86 . The $p f c r t$ gene carried SNPs in codons 72 and 76 in all Brazilian isolates. All isolates presented non-synonymous mutations (Table 5). The P. falciparum isolate from outside Brazil (Angola, Africa) had no SNPs on the pfcrt or pfmdrl genes.
Table 5 Prevalence of molecular markers associated with $P$. falciparum resistance to chloroquine

\begin{tabular}{|c|c|c|c|}
\hline Gene - codon & $\%$ of mutations & Mutations & Protein change \\
\hline \multicolumn{4}{|l|}{ PfMDR1 } \\
\hline 86 & $0 \%$ & - & - \\
\hline 184 & $100 \%$ & TAT > TाT & $\begin{array}{c}\text { Tyrosine > } \\
\text { Phenylalanine }\end{array}$ \\
\hline 1034 & $84 \%$ & AGT > TGT & Serine $>$ cysteine \\
\hline 1042 & $100 \%$ & $\mathrm{AAT}>\mathrm{GAT}$ & $\begin{array}{l}\text { Asparagine > } \\
\text { Aspartic acid }\end{array}$ \\
\hline 1246 & $100 \%$ & GAT > TAT & $\begin{array}{c}\text { Aspartic acid > } \\
\text { Tyrosine }\end{array}$ \\
\hline \multicolumn{4}{|l|}{ PfCRT } \\
\hline 72 & $100 \%$ & $\mathrm{AAA}>\mathrm{ACA}$ & Lysine $>$ Treonine \\
\hline 76 & $100 \%$ & $\mathrm{TGT}>\mathrm{TCT}$ & Cysteine $>$ Serine \\
\hline
\end{tabular}

\section{Discussion}

Due to the strong impact of chemo-resistance among the malaria parasites to most drugs used in the control of the disease, monitoring the development of resistant phenotypes and genotyping are priorities wherever endemic malaria is present. The in vitro methods used to examine anti-malarial drug sensitivity provide a profile of Plasmodium sensitivity to a variety of drugs, simultaneously assayed. However, a lower in vitro sensitivity of a parasite isolate does not imply drug-resistance in vivo, as other factors can interfere, which are not determined by in vitro tests. The ex vivo tests provide an outline of resistant-circulating phenotypes for each tested drug, provided that an adequate number of patients are examined in a given area. This was not the case for $P$. falciparum in our study: only nine patients were evaluated, reflecting the reduced transmission of this parasite species in Brazil [30]. Determining parasite genotype, performed in parallel, provides further information since mutations in the pfcrt gene alter the CQ flux and/or reduce drug efficacy [31]; and provides data for policy makers to decide the best drug to be prescribed in that area. Ideally, monitoring antimalarial chemo-resistance must be continuous since development and spreading of resistance are dynamic events, changing with time and according to human interventions and other factors such as population migration [32].

The antiplasmodial activity and the molecular profile of resistance by anti-malarial standards like $\mathrm{CQ}$, ART and $\mathrm{MQ}$, confirms $P$. falciparum resistance to CQ only, as demonstrated in ex-vivo tests against $P$. vivax and $P$. falciparum isolates from patients with naturally acquired malaria in the state of Rondônia in the Brazilian Western Amazon, which is substantiated by sequencing of genes related to resistance to anti-malarial drugs.

There is evidence of $P$. vivax resistance to CQ in the state of Amazonas, specifically in the city of Manaus where an increase in the proportion of $P$. vivax malaria parallels an increase of unusual clinical complications 
related to this species [33]. These authors used an in vivo test to assess the efficacy of standard supervised CQ therapy. Among 109 volunteers with P. vivax who completed the in vivo test, 19 had positive blood smears within the 28-days follow-up (one on day 14, three on day 21 , and 15 on day 28). All were then required to undergo an alternative therapy with $\mathrm{MQ}$. In another study performed by the same group, a lower $P$. vivax susceptibility to $\mathrm{CQ}$ through the attainment of $\mathrm{IC}_{50}$ by ELISA assay or using traditional methods $[18,34]$ was examined; they demonstrated that drug-resistance was related to the presence of non-synonymous mutation at pvdhps, pvcrt and pvmdr1.

All $P$. vivax isolates presently studied in the Brazilian Western Amazon were sensitive to CQ in ex vivo assays. Although the threshold of $\mathrm{IC}_{50}$ to define a sample as resistant to CQ is not well established for P. vivax, it has been proposed that the same threshold used for P. falciparum should be used, with $100 \mathrm{nM}$ threshold of CQ [35].

The $\mathrm{IC}_{50}$ for ART and MQ in P. vivax were also examined and they were higher when compared with the values found in $P$. falciparum. It can be due to differences in the stage-specific activities of $C Q, M Q$ and $A Q$ in $P$. vivax, demonstrated here and by Marfut et al. [28]. It may be interesting to compare the susceptibility of $P$. vivax in strains from other regions of the world. This issue remains to be further studied using strains from different places.

Only one point mutation for CQ was studied for $P$. vivax in the pvmdr1 gene codon 976, but other genes were associated with CQ resistance in the Brazilian Amazon, e.g., in the pvdhps gene in codon $382(\mathrm{~S} \rightarrow \mathrm{C})$ [18].

Considering that the severity of $P$. vivax malaria in the state of Amazonas has been attributed to CQ resistance and to the increased levels of pvmdr1 and pvcrt-o compared to the levels expressed by parasites from patients with mild symptoms [36], these genes copy number could also be evaluated. In addition, the $m d r 1$ copy number is strongly associated with recrudescence after artesunatemefloquine administration, and could be used as a surveillance tool for artesunate-mefloquine resistance, as reported in patients in Cambodia $[37,38]$.

In conclusion, in West Amazon, most P. falciparum isolates were $\mathrm{CQ}$ resistance, a data confirmed by parasite genotyping. No mutations were found for $P$. vivax in the region supporting the lower prevalence of this strain in Brazil.

\section{Competing interests}

The authors declare that they have no competing interests.

\section{Authors' contributions}

ACCA and NSA carried out the molecular studies. DBP was the MD who interviewed and treated the patients in the endemic area and ACCA performed the ex vivo and diagnostic exams tests. AUK and LDM conceived the studies, participated in the experimental design and were responsible for the biological tests. AUK was the project leader. All authors read and approved the final manuscript.

\section{Acknowledgements}

We are grateful: to Prof. Luiz Hidelbrando Pereira da Silva, FIOCRUZ-RO, for facilities in the endemic area; Luiz Shozo Ozaki, from Department of Microbiology and Immunology, Virginia Commonwealth- University for suggestions; Karina de Sousa Paula for help with parasitaemia evaluation and Glaecia Nascimento with some in vitro tests; for financial support from the Conselho Nacional de Pesquisas e Desenvolvimento- CNPq - Edital MCT/CNPq n 09/2009 - PRONEX Rede Malária (305314/2009-2); MCTI/CNPq/MS-SCTIEDecit N 40/2012- Doenças Negligenciadas (404455/2012-3) and to CNPQ for fellowships to AUK, ACCA, and NSA; for financial support from Fundação de Amparo a Pesquisa de Minas Gerais - FAPEMIG (Universal, CBB, APQ-01692-11).

\section{Author details}

'Laboratório de Malária, Centro de Pesquisas René Rachou, FIOCRUZ, Av Augusto de Lima 1715, 30190-002 Belo Horizonte, MG, Brazil. Faculdade de Medicina, Universidade Federal de Minas Gerais, Belo Horizonte, MG, Brazil.

${ }^{3}$ Centro de Pesquisas em Medicina Tropical de Rondônia, Porto Velho, Rondônia, Brazil.

Received: 27 November 2013 Accepted: 9 February 2014

Published: 28 February 2014

\section{References}

1. WHO: World Malaria Report 2011. Genev: World Malaria Report; 2011. http:// www.who.int/malaria/world_malaria_report_2011/9789241564403_eng.pdf. Accessed: 27/05/2013.

2. Mueller I, Galinski MR, Baird JK, Carlton JM, Kochar DK, Alonso PL, del Portillo HA: Key gaps in the knowledge of Plasmodium vivax, a neglected human malaria parasite. Lancet Infect Dis 2009, 9:555-566.

3. WHO: World Malaria Report 2012. Geneva: World Health Organization; 2012 http://www.who.int/malaria/publications/world_malaria_report_2012/report/ en/index.html Accessed: 27/09/2013.

4. Ministério da Saúde. 2010. http://bvsms.saude.gov.br/bvs/publicacoes/ guia_pratico_malaria.pdf.

5. Ratcliff $A$, Siswantoro $H$, Kenangalem E, Wuwung M, Brockman A, Edstein MD, Laihad F, Ebsworth EP, Anstey NM, Tjitra E, Price RN: Therapeutic response of multidrug-resistant Plasmodium falciparum and $P$. vivax to chloroquine and sulfadoxine-pyrimethamine in southern Papua, Indonesia. Trans R Soc Trop Med Hyg 2007, 4:351-359.

6. Karunajeewa HA, Mueller I, Senn M, Lin E, Law I, Gomorrai PS, Oa O, Griffin S, Kotab K, Suano P, Tarongka N, Ura A, Lautu D, Page-Sharp M, Wong R, Salman S, Siba P, llett KF, Davis TM: A trial of combination anti-malarial therapies in children from Papua New Guinea. N Engl J Med 2008, 24:2545-2557.

7. Manoempil P, Baird JK, Sutanto I, Suprijanto S, Nurhayati: Resistance to chloroquine by Plasmodium vivax at Alor in the Lesser Sundas Archipelago in eastern Indonesia. Am J Trop Med Hyg 2009, 2:338-342.

8. Suwanarusk R, Russell B, Chavchich M, Chalfein F, Kenangalem E, Kosaisavee V, Prasetyorini B, Piera KA, Barends M, Brockman A, Lek-Uthai U, Anstey NM, Tjitra E, Nosten F, Cheng Q, Price RN: Chloroquine resistant Plasmodium vivax: in vitro characterisation and association with molecular polymorphisms. PLoS One 2007, 10:e1089.

9. Price RN, Douglas NM, Anstey NM: New developments in Plasmodium vivax malaria: severe disease and the rise of chloroquine resistance. Curr Opin Infect Dis 2009, 22:430-435.

10. Alexandre MA, Ferreira CO, Siqueira AM, Magalhães BL, Mourão MP, Lacerda MV, Alecrim MD: Severe Plasmodium vivax malaria, Brazilian Amazon. Emerg Infect Dis 2010, 16:1611-1614

11. Andrade BB, Reis-Filho A, Souza-Neto SM, Clarêncio J, Camargo LM, Barral A, Barral-Netto M: Severe Plasmodium vivax malaria exhibits marked inflammatory imbalance. Malar J 2010, 9:13.

12. Lanca EF, Magalhaes BM, Vitor-Silva S, Siqueira AM, Benzecry SG, Alexandre MA, Brien CO, Bassat Q, Lacerda MV: Risk factors and characterization of Plasmodium vivax-associated admissions to pediatric intensive care units in the Brazilian Amazon. PLoS One 2012, 7:e35406.

13. Wélé M, Djimdé AA, Guindo A, Beavogui AH, Traoré IZ, Sadou A, Blaise D, Diallo DA, Wellems TE, Doumbo OK: High frequency of PfCRT 76T in two Malian villages and its prevalence in severe relative to non-severe malaria. Acta Trop 2011, 119:11-13. 
14. Dondorp AM, Nosten F, Yi P, Das D, Phyo AP, Tarning J, Lwin KM, Ariey F, Hanpithakpong W, Lee SJ, Ringwald P, Silamut K, Imwong M, Chotivanich K, Lim P, Herdman T, An SS, Yeung S, Singhasivanon P, Day NP, Lindegardh N, Socheat $D$, White NJ: Artemisinin resistance in Plasmodium falciparum malaria. N Engl J Med 2009, 361:455-467.

15. Miotto O, Almagro-Garcia J, Manske M, Macinnis B, Campino S, Rockett KA Amaratunga C, Lim P, Suon S, Sreng S, Anderson JM, Duong S, Nguon C, Chuor CM, Saunders D, Se Y, Lon C, Fukuda MM, Amenga-Etego L, Hodgson AV, Asoala V, Imwong M, Takala-Harrison S, Nosten F, Su XZ, Ringwald P, Ariey F, Dolecek C, Hien TT, Boni MF, et al: Multiple populations of artemisinin-resistant Plasmodium falciparum in Cambodia. Nat Genet 2013, 45:648-655.

16. Rijken MJ, Boel ME, Russell B, Imwong M, Leimanis ML, Phyo AP, Muehlenbachs A, Lindegardh N, McGready R, Rénia L, Snounou G, Singhasivanon $\mathrm{P}$, Nosten $\mathrm{F}$ : Chloroquine resistant vivax malaria in a pregnant woman on the western border of Thailand. Malar J 2011, 10:113.

17. Alecrim MG, Alecrim W, Macedo V: Plasmodium vivax resistance to chloroquine (R2) and mefloquine (R3) in Brazilian Amazon region. Rev Soc Bras Med Trop 1999, 32:67-68.

18. Chehuan YF, Costa MR, Costa JS, Alecrim MG, Nogueira F, Silveira H, Brasil LW, Melo GC, Monteiro WM, Lacerda MV: In vitro chloroquine resistance for Plasmodium vivax isolates from the Western Brazilian Amazon. Malar J 2013, 12:226

19. Sidhu AB, Verdier-Pinard D, Fidock DA: Chloroquine resistance in Plasmodium falciparum falciparum malaria parasites conferred by pfcrt mutations. Science 2002, 298:210-213.

20. Wongsrichanalai C, Pickard AL, Wernsdorfer WH, Meshnick SR: Epidemiology of drug-resistant malaria. Lancet Infect Dis 2002, 2:209-218.

21. Wellems TE, Plowe CV: Chloroquine-resistant malaria. J Infect Dis 2001, 184:770-776.

22. Rieckmann KH, López Antuñano FJ: Chloroquine resistance of Plasmodium falciparum in Brazil detected by a simple in vitro method. Bull World Health Organ 1971, 45:157-167.

23. Renapurkar DM, Pradhan VR, Sutar NK, Deshmukh RA, Pandit CH, Marathe $\mathrm{SN}$ : Micro test for assaying sensitivity of Plasmodium vivax in vitro. Chemotherapy 1989, 3:160-163.

24. Russell BM, Udomsangpetch R, Rieckmann KH, Kotecka BM, Coleman RE, Sattabongkot J: Simple in vitro assay for determining the sensitivity of Plasmodium vivax isolates from fresh human blood to anti-malarials in areas where P. vivax is endemic. Antimicrob Agents Chemother 2003, 47:170-173.

25. Sriprawat K, Kaewpongsri S, Suwanarusk R, Leimanis ML, Lek-Uthai U, Phyo AP, Snounou G, Russell B, Renia L, Nosten F: Effective and cheap removal of leukocytes and platelets from Plasmodium vivax infected blood. Malar J 2009, 8:115.

26. Trager $W$, Jensen J: Human malaria parasites in continuous culture. Science 1976, 193:673-675.

27. Mangold KA, Manson RU, Koay ES, Stephens L, Regner M, Thomson RB Jr, Peterson LR, Kaul KL: Real-time PCR for detection and identification of Plasmodium spp. J Clin Microbiol 2005, 43:2435-2440.

28. Marfurt J, Chalfein F, Prayoga P, Wabiser F, Wirjanata G, Sebayang B, Piera KA, Wittlin S, Haynes RK, Möhrle JJ, Anstey NM, Kenangalem E, Price RN: Comparative ex vivo activity of novel endoperoxides in multidrugresistant Plasmodium falciparum and $P$. vivax. Antimicrob Agents Chemother 2012, 56:5258-5263.

29. Marfurt J, Chalfein F, Prayoga P, Wabiser F, Kenangalem E, Piera KA, Fairlie DP, Tjitra E, Anstey NM, Andrews KT, Price RN: Ex vivo activity of histone deacetylase inhibitors against multidrug-resistant clinical isolates of Plasmodium falciparum and P. vivax. Antimicrob Agents Chemother 2011, 55:961-966.

30. SVS, Serviço de Vigilância Sanitária. ; 2013. http://dw.saude.gov.br/gsid/ servlet/mstr Accessed: 27/09/2013.

31. Fidock DA, Nomura T, Talley AK, Cooper RA, Dzekunov SM, Ferdig MT, Ursos LM, Sidhu AB, Naudé B, Deitsch KW, Su XZ, Wootton JC, Roepe PD, Wellems TE: Mutations in the $P$. falciparum digestive vacuole transmembrane protein PfCRT and evidence for their role in chloroquine resistance. $\mathrm{Mol}$ Cell 2000, 6:861-871

32. Carvalho $L$, Daniel-Ribeiro $C T$, de Fátima Ferreira-da-Cruz M, Bianco-Junior C, Druilhe P, Brasseur P, Siqueira MJ, das Graças Alecrim M, Pratt-Riccio LR, Chehuan YF, Siqueira MJ: Use of a colorimetric (DELI) test for the evaluation of chemoresistance of Plasmodium falciparum and Plasmodium vivax to commonly used anti-plasmodial drugs in the Brazilian Amazon. Malar $J$ 2013, 12:281.

33. de Santana Filho FS, Arcanjo AR, Chehuan YM, Costa MR, Martinez-Espinosa FE, Vieira JL, Barbosa M, Alecrim WD, Alecrim MD: Chloroquine-resistant Plasmodium vivax in the Brazilian Amazon. Emerg Infect Dis 2007, 13:1125-1126.

34. Orjuela-Sánchez P, de Santana Filho FS, Machado-Lima A, Chehuan YF, Costa MR, Alecrim M, del Portillo HA: Analysis of single-nucleotide polymorphisms in the crt-o and mdr1 genes of Plasmodium vivax amongchloroquine-resistant isolates from the Brazilian Amazon region. Antimicrob Agents Chemother 2009, 53:3561-3564.

35. Druilhe P, Brasseur P, Blanc C, Makler M: Improved assessment of Plasmodium vivax response to anti-malarial drugs by a colorimetric double-site Plasmodium lactate dehydrogenase antigen capture enzyme-linked immunosorbent assay. Antimicrob Agents Chemother 2007 51:2112-2116

36. Fernández-Becerra C, Pinazo MJ, González A, Alonso PL, del Portillo HA, Gascón J: Increased expression levels of the pvcrt-o and pvmdr1 genes in a patient with severe Plasmodium vivax malaria. Malar J 2009, 8:55.

37. Suwanarusk R, Russell B, Chavchich M, Chalfein F, Kenangalem E, Kosaisavee V, Prasetyorini B, Piera KA, Barends M, Brockman A, Lek-Uthai U, Anstey NM, Tjitra E, Nosten F, Cheng Q, Price RN: Chloroquine resistant Plasmodium vivax: in vitro characterisation and association with molecular polymorphisms. PLoS One 2007, 2:e1089.

38. Lek-Uthai U, Suwanarusk R, Ruengweerayut R, Skinner-Adams TS, Nosten F, Gardiner DL, Boonma P, Piera KA, Andrews KT, Machunter B, McCarthy JS, Anstey NM, Price RN, Russell B: Stronger activity of human immunodeficiency virus type 1 protease inhibitors against clinical isolates of Plasmodium vivax than against those of P. falciparum. Antimicrob Agents Chemother 2008, 7:2435-2441.

doi:10.1186/1475-2875-13-73

Cite this article as: Aguiar et al.: Plasmodium vivax and Plasmodium

falciparum ex vivo susceptibility to anti-malarials and gene

characterization in Rondônia, West Amazon, Brazil. Malaria Journal 2014 13:73

\section{Submit your next manuscript to BioMed Central and take full advantage of:}

- Convenient online submission

- Thorough peer review

- No space constraints or color figure charges

- Immediate publication on acceptance

- Inclusion in PubMed, CAS, Scopus and Google Scholar

- Research which is freely available for redistribution

Submit your manuscript at www.biomedcentral.com/submit
C BioMed Central 